\title{
Tolerance and Biosorption of Manganese, Iron and Aluminium by Five Aspergillus Species Isolated from Freshwater
}

\author{
A. H. Mahmoud ${ }^{1}$, M. S. Massoud ${ }^{2 *}$, F. F. Abdel-Motaal ${ }^{2}$, S. A. El-Zayat ${ }^{2}$ \\ ${ }^{1}$ Company of Drinking Water and Sanitation, Luxor, Egypt \\ ${ }^{2}$ Botany Department, Faculty of Science, Aswan University, Aswan, Egypt
}

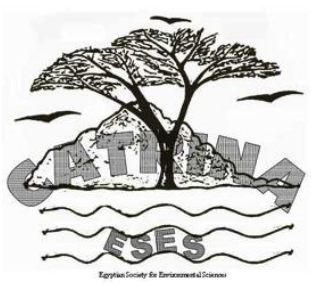

\begin{abstract}
Microorganisms play a significant role in bioremediation of heavy metal contaminated soil and wastewater. The present study has been carried out to understand the tolerance potential of different species of Aspergillus (A. flavus, A. niger, A. nidulans, A. oryzae and A. terreus) which were isolated from the Nile water. The degree of tolerance of fungi was measured by minimum inhibitory concentration in the presence of different concentration of metals $(\mathrm{Mn}, \mathrm{Fe}$ and $\mathrm{Al}$ ) and compared to a control sample. Results showed variations in the tolerance level of different isolates of Aspergillus. A. niger and $A$. oryzae were tolerant while A. nidulans was the most sensitive species. Removal of manganese, iron, and aluminium using powder and viable Aspergillus oryzae biomass was investigated. Metals ( $\mathrm{Mn}, \mathrm{Fe}$. and $\mathrm{Al}$ ) removal increased with an increasing dose of biosorbent for the powder and viable biomass within two hours. These results showed that powder and viable Aspergillus oryzae biomass can be used for removal of heavy metals from polluted water.
\end{abstract}

Keywords: Aspergillus, A. oryzae, bioremediation, heavy metals, resistance.

\section{INTRODUCTION}

Contamination of sediments and natural aquatic receptors with different pollutant is a major environmental problem all over the world (Baldrian and Gabriel, 2002; Gavrilesca, 2004; Malik, 2004; Nontokozo et al., 2017). Industrialization and urbanization especially in developing countries have led to the accumulation of heavy metals and petroleum hydrocarbons in the environment (Bamgbose and Sibanjo, 1998; Byomi et al., 1999; Manay et al., 1999; Ngodigha et al., 1999; Yamasoet et al., 2000; Adeniyi and Folabi, 2002; Monika et al., 2017). Metals that are released into the environment tend to persist indefinitely, accumulating into living tissues and posing a serious threat to the environment and public health. These harmful substances accumulate in crops via food chain; find their way into our bodies, where they can cause a variety of illness. They are cytogenic mutagenic, and carcinogenic in nature and are posing threats to the urban population, which rely on vegetables and foliage crops grown in pre-urban lands. Introduction of heavy metals into environment generally induces morphological and physiological changes in microbial communities (Vadkertiova and Slavikova, 2006; Monisha et al., 2014), hence exerting a selective pressure on the microbiota (Verma et al., 2001). These contaminated sites are the source of metal resistance microorganisms (Gadd, 1993).

Among all living organisms, fungi are very important microorganism; it can tolerate heavy metals to a limit and can also help to remove heavy metals from contaminated soil. Fungi and yeast biomasses are known to tolerate heavy metals (Khan, 2001; Baldrian, 2003; Gavrilesca, 2004; Ding et al., 2016; Fawzy et al., 2017) to achieve implementation of fungal heavy metal biosorption technology in environmental remediation requires a better understanding of influencing parameters, including initial concentrations, physic-chemical conditions and also contact times. Successful biosorption processes require inexpensive biomaterials display high metal uptake and selectivity based on a biochemical constitution, as well as suitable mechanical properties for applied remediation procedures. In bio-sorption, either viable or powder microorganism or their derivatives are used, which complex metal ions through the action of ligands or functional groups located on the outer surface of the cell (Bolton and Gorby, 1995). Biosorption regarded as physicochemical interactions of metal ions with the cellular compounds of biological species (Kapoor and Viraraghavan, 1997). The mechanism of uptake can be due to ion exchange, chelation, chemical complexation with microbial cell surface groups, adsorption and diffusion through cell wall and membranes (Kuyucak and Volesky, 1988; Churchill et al., 1995; Vaishalya et al., 2015) which differ depending on the species used, the origin and processing of the biomass and solution chemistry. These elements were measured in some areas which related to the company of drinking water and sanitation, and it was higher than values within the standards and specifications to be met in water for drinking and domestic uses. The aim of the present study was to check the tolerance potential of different species of Aspergillus to manganese, iron, and aluminium. The removal efficiency of these heavy metals by A. oryzae was followed by different factors like growth period and biosorption dose.

\section{MATERIALS AND METHODS}

\section{Determination of temperature and $\mathrm{pH}$ value}

Nile water temperature and $\mathrm{pH}$ values were measured instrumentally using instrument (Hach hq 430). 


\section{Microorganisms and growth conditions}

Fungal strains used in this study including five species of Aspergillus (A. flavus, A. nidulans, A. niger, A. terreus and $A$. oryzae) were isolated from five sites of fresh water (River Nile at Luxor city area) and identified according to (Raper and Fennell, 1965; Gams et al., 1985; Geiser et al., 2008), were tested for their resistance and growth in the presence of various concentration of metals ( $\mathrm{Mn}, \mathrm{Fe}$ and $\mathrm{Al}$ ). These microorganisms were grown in Glucose-Czapek's agar medium which consisted of $1 \mathrm{~L}$ distilled water, $1 \mathrm{gm} / 1$ $\mathrm{K}_{2} \mathrm{HPO}_{4}, 3.0 \mathrm{~g} / \mathrm{l} \mathrm{NaNO} 3,0.5 \mathrm{~g} / 1 \mathrm{MgSO}_{4}, 0.5 \mathrm{~g} / \mathrm{l} \mathrm{KCl}$, $0.01 \mathrm{~g} / 1 \mathrm{FeSO}_{4} \cdot 7 \mathrm{H}_{2} \mathrm{O}, 10 \mathrm{~g} / \mathrm{l}$ glucose and $15 \mathrm{~g} / \mathrm{l}$ agar. The strains were then allowed to grow at $28^{\circ} \mathrm{C}$ in an incubator.

\section{Determination of minimum inhibitory concentration (MIC)}

The (MIC) is defined as the lowest concentration of metals that inhibit visible growth of isolates. The tolerance of selected isolates to $\mathrm{Mn}, \mathrm{Fe}$ and $\mathrm{Al}$ was determined by dilution method $(1,10,20,30,50,100,300,500$ and $1000 \mathrm{ppm}$ of metal ions (Rice et al., 2012), were added separately to glucose Czapek's agar medium. The plates were inoculated with $8 \mathrm{~mm}$ agar plugs of young fungal colonies, pre-grown on Czapek's medium for 7 days. Three replicates of each concentrate and controls without metal were used. The inoculated plates were incubated at $28^{\circ} \mathrm{C}$ for $7-15$ days. The effects of heavy metals on the growth were estimated by measuring the radius of the colony extension $(\mathrm{mm})$ against the control for determination of their tolerance.

\section{Preparation of Aspergillus oryzae biomass for rem- oval studies}

Aspergillus oryzae was selected based on its frequent occurrence during sampling. An inoculum of active growing fungal culture was transferred to $500 \mathrm{ml}$ conical flask containing malt extract-peptone broth medium (Samson et al., 1996) and incubated at $28^{\circ} \mathrm{C}$ for 15 days. Fungal biomass was harvested and washed twice by sterile bi-distilled water, then this biomass was drained and represented viable biomass. A constant weight of viable biomass was dried at $55^{\circ} \mathrm{C}$ for $24 \mathrm{~h}$ and ground with a mortar to make powder biomass.

\section{Effect of biomass concentration}

To evaluate the effect of viable and powder biomass on the adsorption behavior of $\mathrm{Mn}, \mathrm{Fe}$ and $\mathrm{Al} ; 1,2$ and 3 $\mathrm{g}$ of biomass were added to separate $(250 \mathrm{ml})$ Erlenmeyer flask. Aliquots $(100 \mathrm{ml})$ of heavy metal concentrations $(1,10,30,50,100,300,500$ and $1000 \mathrm{ppm})$ were added to each flask and the flasks were shacked for $60 \mathrm{~min}$. at room temperature before being analyzed.

\section{Contact time}

To determine the optimal incubation time, a fixed adsorbent concentration of $1 \mathrm{~g}$ of fungal biomass (viable and powder) was added to $100 \mathrm{ml}$ of heavy metal concentrations with continuous shacking at room temperature before analysis. All samples were analyzed by Dr 5000 automatic adsorption spectrophotometry at wave length $(525,510 \mathrm{~nm})$ for all examined metals.

\section{RESULTS}

Physico-chemical characteristics of the Nile water samples showed that; temperatures of all water samples ranged between $27.4^{\circ} \mathrm{C}$ and $39.9^{\circ} \mathrm{C}$. The $\mathrm{pH}$ value of the Nile water samples fluctuated between 7.0 and 8.6. Long-time exposure of water and sediment to heavy metals can produce considerable modification of their microbial populations, reducing their activity and their number.

Fungi are natural inhabitants of soil and water; they have greater potential for remediation virtue of their aggressive growth, greater biomass, production and extensive hyphal reach to its habitat. Results of the present study depicted that the tested isolates; Aspergillus flavous, A. nidulanse, A. niger, A. oryza and $A$. terreus) show different tolerance behavior for different heavy metals. Some isolates were sensitive, moderately tolerant and tolerant (Fig. 1). These isolates are tested to determine the minimum inhibitory concentration (MIC) for the metals. The order of toxicity of metals to $(A$. flavus, A. niger, A. oryzae and A. terreus were $\mathrm{Mn}>\mathrm{Al}$ $>\mathrm{Fe}, \mathrm{Mn}>\mathrm{Fe}>\mathrm{Al}, \mathrm{Mn}>\mathrm{Fe}>\mathrm{Al}$ and $\mathrm{Al}>\mathrm{Fe}>\mathrm{Mn}$, respectively.

Figure (1) showed that the growth of most tested isolates markedly decreased with increasing metal concentration. The growth of A. flavus decreased to approximately more than $50 \%$ at 300 and 500 ppm of $\mathrm{Mn}$ and completely inhibited at $1000 \mathrm{ppm}$.

Aspergillus nidulans and A. terreus sharply decreased by about $60 \%$ when they grow at $30 \mathrm{ppm}$ of $\mathrm{Fe}$ and completely inhibited at 50,100, 300, 500 and 1000 ppm. A. niger showed exactly contrasting behavior with Fe. Its growth increased at 1, 10 and 30 ppm then decreased with increasing concentration to 50, 100 and 300 ppm. No growth at 500 and 1000 ppm was observed. The growth of Aspergillus flavus and A. oryzae exhibited considerable tolerance toward aluminum, while higher concentrations of $\mathrm{Al}$ (500 and $1000 \mathrm{ppm}$ ) failed completely the growth of $A$. nidulans and A. terreus.

\section{Influence of biosorpent dose on metals uptake by $A$. oryzae}

The uptake of metals by fungal biomass appears to involve a combination of two processes namely bioaccumulation and biosorption. Bioaccumulation is an active metabolism-dependent process, and may include both transport into the cell and partitioning into intercellular components. Biosorption based on the binding of metals to the biomass by processes that do not require metabolic energy.

Manganese, iron and aluminum were investigated by various biosorpent doses (1.0, 2.0 and $3.0 \mathrm{~g} / \mathrm{l})$ with different concentrations of metals (1 - 1000 ppm). 
Generally, 1 ppm dose of the three studied metals showed the highest adsorption percentage with viable and powder biomass concentrations (Fig. 2).

On the other hand, our results revealed a marked increase in removal of all tested metals by the increa- sing of biosorpent mass (Fig. 2). The maximum removal efficiency was observed at $3.0 \mathrm{~g}$ of powder biomass 58 , 69, $71.9 \%$ for $1.0 \mathrm{ppm}$ of $\mathrm{Mn}, \mathrm{Fe}$ and $\mathrm{Al}$ ions respectively. While with viable biomass, it was slightly lower $(51,56,69 \%)$ for $\mathrm{Mn}, \mathrm{Fe}$ and $\mathrm{Al}$, respectively.
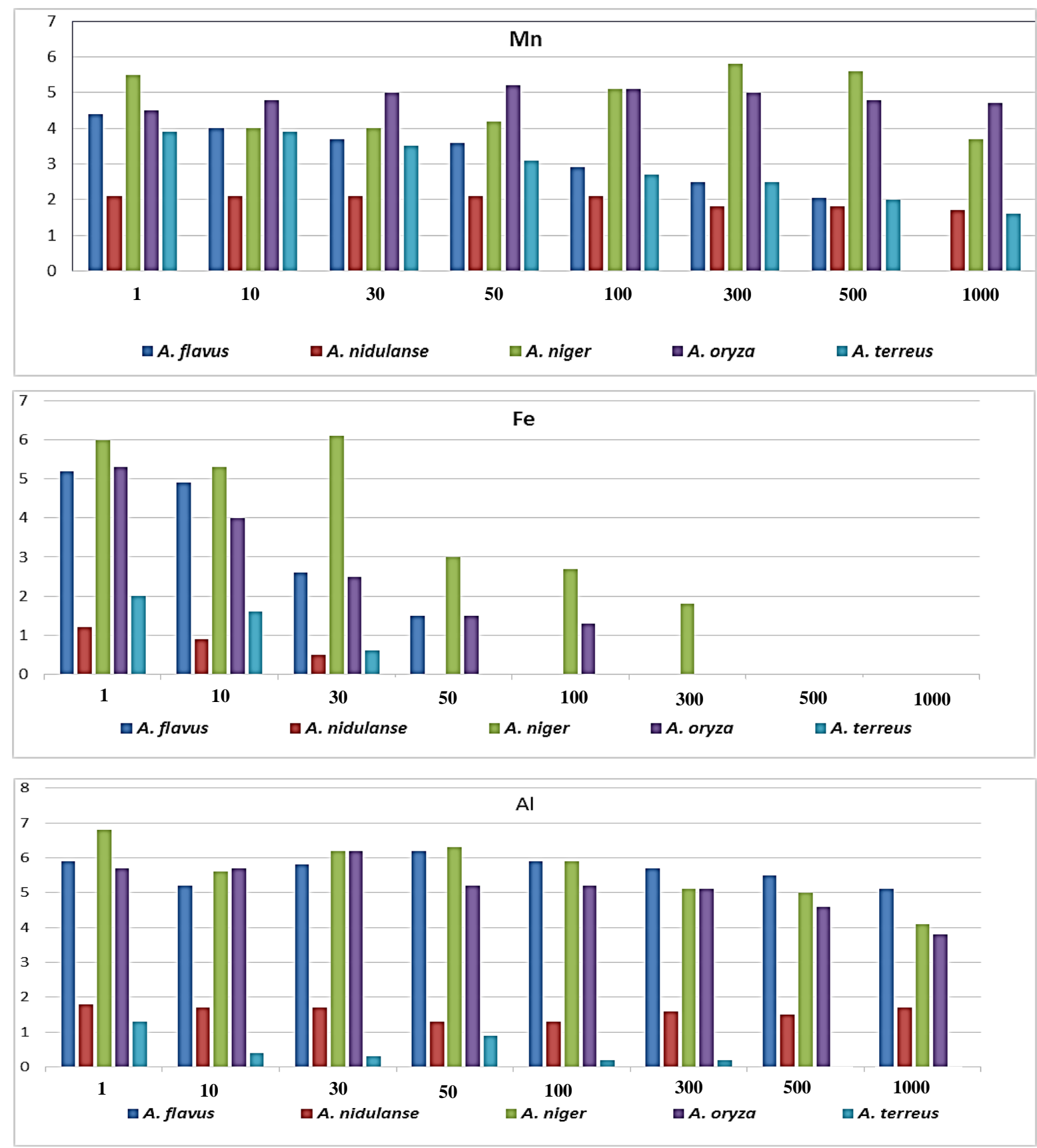

Figure (1): Effect of different concentrations of heavy metals (Mn, Fe and $\mathrm{Al}$ ) on growth of five species of Aspergillus . 


\section{Live biomass}

豆
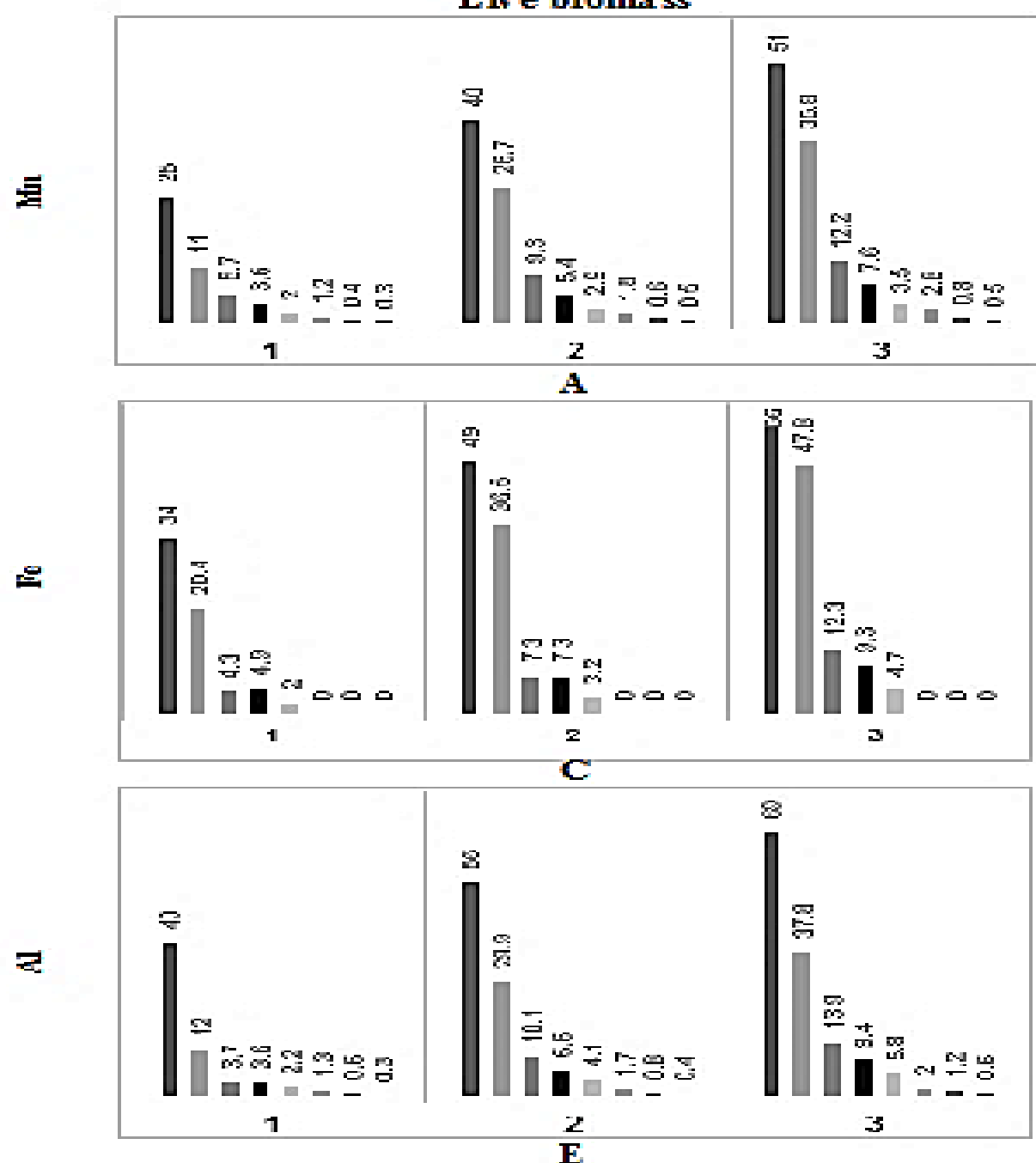

\section{Dead biomass}

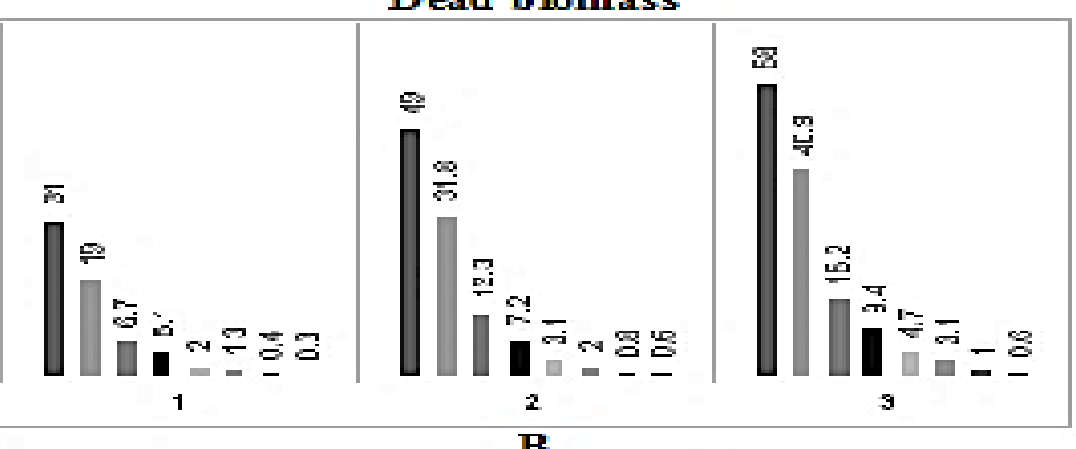

$\mathbf{B}$
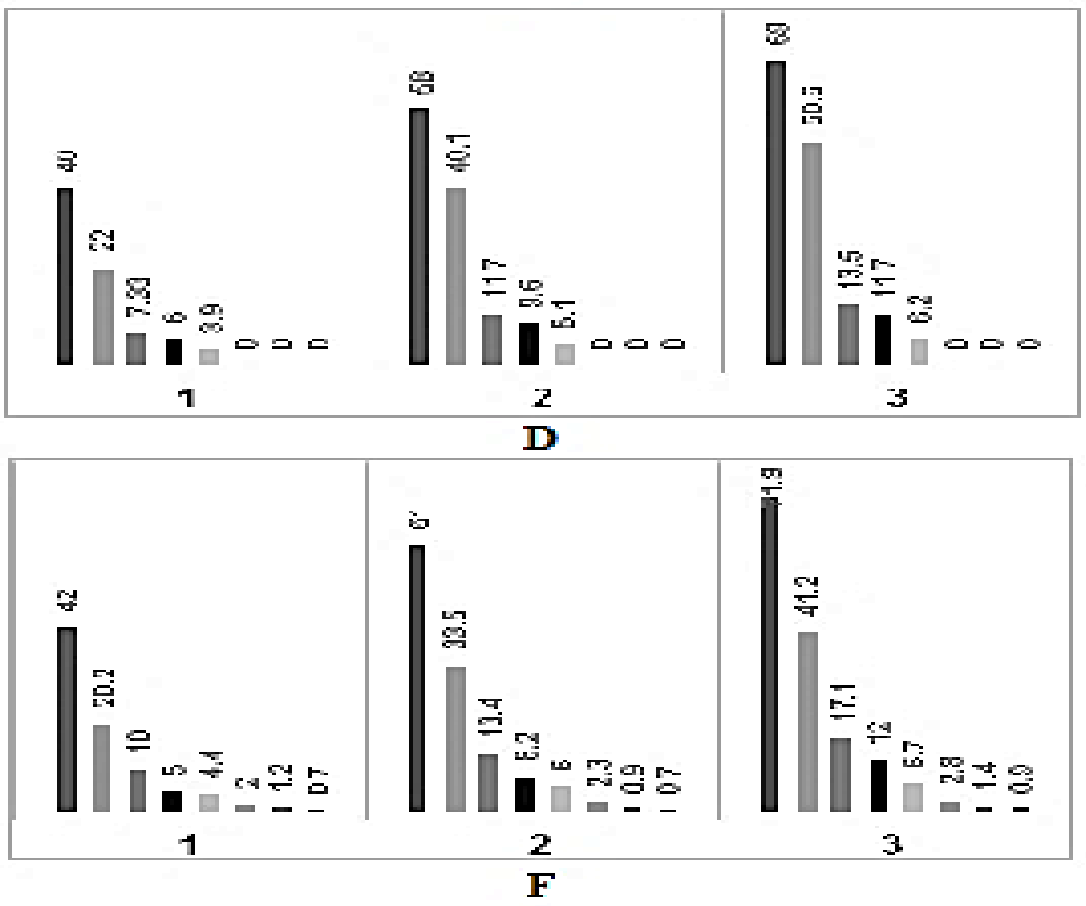

Figure. (2): Effect of the fungal biomass (Live and Dead) and dose on the biosorption percentage of Mn. (a and b), $\mathrm{Fe}$ (c and d) and $\mathrm{Al}$ (e and f) by A. oryzae 
Live biomass

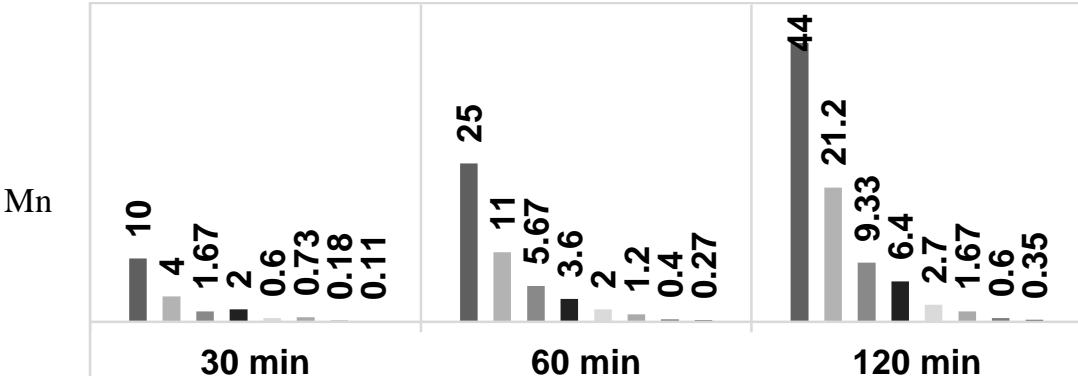

A

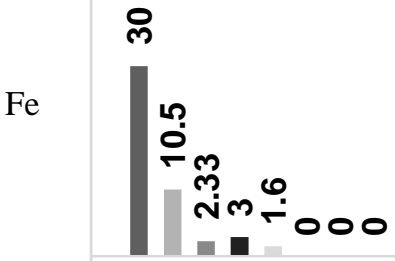

30 MIN

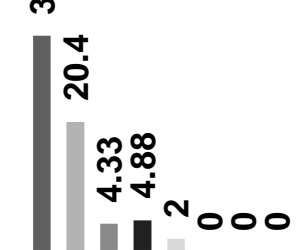

$60 \mathrm{MIN}$

Al

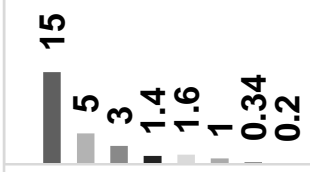

$30 \mathrm{~min}$

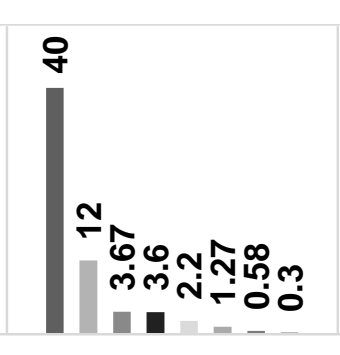

$60 \mathrm{~min}$

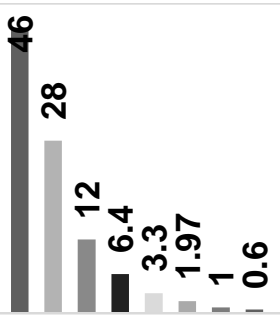

$120 \mathrm{~min}$

Dead biomass

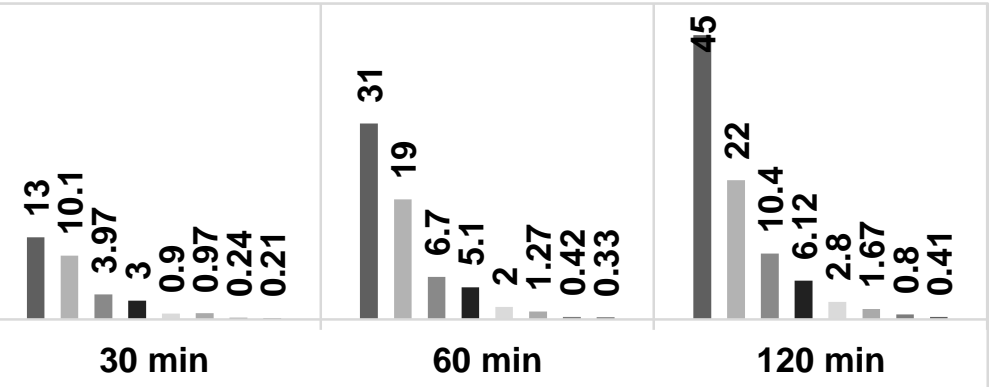

B

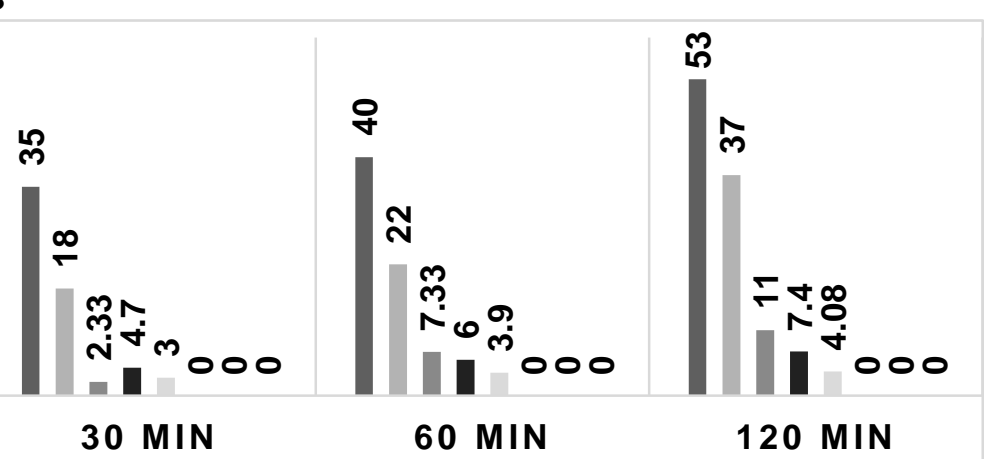

E

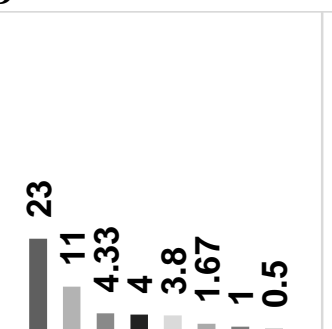

$30 \mathrm{~min}$

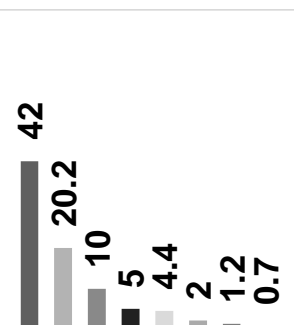

$60 \mathrm{~min}$

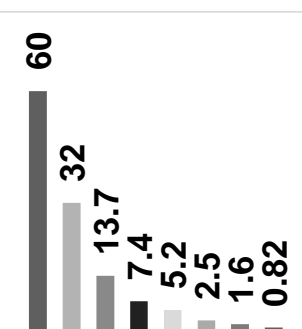

$120 \mathrm{~min}$

Figure (3): Effect of the fungal exposed time (30,60 and $120 \mathrm{~min}$ ) contact on the percentage of Manganese (a and b), Iron (c and d) and Aluminum (e and F) biosorption by A. oryzae. 
Effect of contact time on the metal uptake by $\boldsymbol{A}$. oryzae.

The results illustrated in figure (3), indicated that the level of ion uptake rose with increasing time contact. Uptake of $\mathrm{Mn}, \mathrm{Fe}$ and $\mathrm{Al}$ ions by viable biomass of $A$. oryzae increased with increasing contact time from 30 $\min$ to $120 \mathrm{~min}$. High removal rates of $44 \%, 51 \%$ and $46 \%$ for $\mathrm{Mn}, \mathrm{Fe}$ and $\mathrm{Al}$ ions, respectively were recorded at $120 \mathrm{~min}$ when the metal concentration maintained at $1.0 \mathrm{ppm}$. Biosorption percentage decreased with increasing metals concentration with low removal rates $0.11 \%, 1.6 \% .0 .2 \%$ for $\mathrm{Mn}, \mathrm{Fe}$ and $\mathrm{Al}$ ions respectively, at $30 \mathrm{~min}$ when the metal concentration maintained at (1000 ppm for $\mathrm{Mn}$ and $\mathrm{Al}$ ) and at metal concentration $100 \mathrm{ppm}$ for $\mathrm{Fe}$. On the other hand, removal rate by powder biomass of $A$. oryzae was higher than that of viable biomass with increasing contact time from 30 min to $120 \mathrm{~min}$. High removal rate $(45 \%, 53 \%, 60 \%)$ for ( $\mathrm{Mn}, \mathrm{Fe}$ and $\mathrm{Al}$ ions) respectively, at $120 \mathrm{~min}$ when the metal concentration maintained at $1.0 \mathrm{ppm}$. Biosorption percentage also decrease with increasing metals concentration, low percentage of biosorption was clearly observed at $30 \mathrm{~min}$ with concentration (1000 ppm for $\mathrm{Mn}$ and $\mathrm{Al}$ ) and at metal concentration $100 \mathrm{ppm}$ for $\mathrm{Fe}$ the percentage estimate $(0.5 \%, 3 \%$ and $0.5 \%)$ for $(\mathrm{Mn}$, $\mathrm{Fe}$ and $\mathrm{Al}$ ions) but this percentage of biosorption more than Viable biomass.

The biosorptive capacity of fungal cells powder has been studied extensively in comparison to living cells. Systems using living cells are likely to be more sensitive to metal ion concentration (toxicity effects) and adverse operating conditions ( $\mathrm{pH}$ and temperature). Furthermore, constant nutrient supply is required for systems using living cells (increased operating cost for waste streams devoid of nutrients) and recovery of metals and regeneration of biosorpent is more complicated for living cells. The biosorptive capacity of powder cells may be greater than that of living cells. Use of powder biomass in industrial applications offers certain advantages over living cells.

\section{DISCUSSION}

Heavy metals contamination has become a serious threat for the environmental safety, pressurizing soils, water streams, atmosphere and living systems. Generation of large quantities of toxic effluents containing metals, metalloids, lanthanides and radio-nuclides are deteriorating biodiversity, ecosystem and human safety. Fungi are versatile group as they can adapt and grow under various extreme condition of $\mathrm{pH}$, temperature and nutriaent availability, as well as high metal concentrations (Anand et al., 2006). They offer the advantage of having cell wall material which shows excellent metal binding properties (Gupta et al., 2000). Describing the ability to grow at high metal concentrations, (Malik, 2004) distinguished tolerant to more rapidly comparing with that of higher concentrations (Ahalya et al., 2005). They were marked increase in removal of all tested metals by the increasing of biosorpent mass during these investigation, the results were in harmony with the previous work by: Jayaraman and Arumugam (2014) which recorded that; increase of the availability of free adsorption sites and the adsorption surface area help in removal of metals, during their work in Metal tolerance analysis of micro fungi isolated from metal contaminated soil and waste water. The maximum removal efficiency was observed at $3.0 \mathrm{~g}$ of powder biomass 58, 69, 71.9\% for $1.0 \mathrm{ppm}$ of $\mathrm{Mn}, \mathrm{Fe}$ and $\mathrm{Al}$ ions respectively. While with viable biomass, it was slightly lower $(51,56$, and $69 \%$ ) for $\mathrm{Mn}, \mathrm{Fe}$ and $\mathrm{Al}$, respectively. Similar enhancement in powder mass of A. oryzae was a feasible and favorable process in adsorption of aluminum ions by Omeike et al. (2013)

\section{Effect of contact time on the metal uptake by $A$. oryzae.}

The uptake of $\mathrm{Mn}, \mathrm{Fe}$ and $\mathrm{Al}$ ions by viable biomass of $A$. oryzae increased with increasing contact time from $30 \mathrm{~min}$ to $120 \mathrm{~min}$. The maximum amounts were recorded at $120 \mathrm{~min}$ when the metal concentration maintained at $1.0 \mathrm{ppm}$. Biosorption percentage decree-sed with increasing metals concentration with low removal rates for tested metals at $30 \mathrm{~min}$ at concentration (1000 ppm for $\mathrm{Mn}$ and $\mathrm{Al}$ ) and at concentration $100 \mathrm{ppm}$ for Fe. High removal rate by powder biomass of $A$. oryzae was higher than that of viable biomass with increasing contact time from $30 \mathrm{~min}$ to $120 \mathrm{~min}$. Use of powder biomass in industrial applications offers certain adventages over living cells. The powder biomass can be procured from industrial sources as a waste product from established fermentation processes (Kapoor and Viraraghavan, 1997)

\section{CONCLUSIONS}

According to our knowledge, limited work in A. oryzae adsorption ability to aluminum and almost no previous work in the ability of this fungus adsorbent to iron and manganese. Thus, A oryzae biomass adsorption potency is a promising ecofriendly tool to clean up water from manganese, iron and aluminum Aspergillus oryzae appeared to be a suitable candidate for wastewater bioremediation. Further research will assist optimization of final biosorption capacity to improve the economic sustainability and practicalities of large-scale implementation of fungal heavy metal bioremediation. Finally, we conclude that, Aspergillus is a potential method to clean environment from toxic element with a promised feedback to use powder biomass to avoid any contamination by fungus.

\section{REFERENCES}

ABDULWAHAB, R.H.B. 2015. Fungal absorption and tolerance of heavy metals. J. Agricultural Science 
and Technology B 5: 77-80.

ADENIYI, A. A. AND J. A. FOLAB. 2002. Determination of total petroleum hydrocarbons and heavy metals in soils within the vicinity of facilities handling refined petroleum products in logos metropolis, Journals of Environment International 28: 79-82.

AHALYA, N., R. D. KANAMADI, AND T. V. RAMACHANDRA. 2005. Biosorption of Chromium (VI) from aqueous solutions by the husk of Bengal gram (Cicer avientinum). Electron. Journal of Biotechnology. 8(3): 257-264.

ANAND, P., J. ISAR, S. SARAN, AND R.K. SAXENA. 2006. Bioaccumulation of copper by Trichoder-ma viride, Bioresoure Technology 97: 1018-1025.

BALDRIAN, P. 2003. Interactions of heavy metals with white-rot fungi. Enzyme Microbiological Technology 32: 78-91.

BALDRIAN, P., AND J. GABRIEL. 2002. Intraspecific variability in growth response to cadmium of the wood-rotting fungus Piptoporus betulinus, Mycologia 94: 428-436.

BAMGBOSE, O. AND O. SIBANJO. 1998. Comparative assessment of three methods for cholorinated hydrocarbon determination in fish, Mig. Journal of Science 32: 169-174.

BOLTON, H., AND Y. A. GORBY. 1995. An overview of the bioremediation of metal-contaminated industrial effluents using waste sludges. Water Sci. Technol. 34: 9-15.

BYOMI, A. M., M. HASSAN, R. S. SALEH, E. I. EAMROURI, S. A.YOUSEF, AND A. A. AAMER. 1999. Population of waste and animals feed with some heavy metals and their implication in raw buffalo milk. In proceeding of the 5th scientific congress Egyptian soc, For cattle diseases Egypt 28: 226-230.

CHURCHILL, S. A., J. V. WALTERS, AND P. F. CHURCHILL. 1995. Sorption of heavy metals by pre-pared bacterial cell surfaces. J. Environ. Eng. 121: 706-711

DING, Z., J. WU, C. JIAO, AND C. CAO. 2016. Isolation of heavy metal-resistant fungi from contaminated soil and co-culturing with rice seedlings. Afr. J. Microbiol. Res. Vol.10 (28): 1080-1085.

FAWZY, E. M., F. F. ABDEL-MOTAAL, AND S. A. EL-ZAYZT. 2017. Biosorption of heavy metals onto different eco-friendly substrates. J. Toxicol. Environ. Health Sci. Vol. 9(5): 35-44.

GADD, G. M. 1993. Interaction of fungi with toxic metals. New Phytol. 124, 24.GADD, G. M. AND GRIFFITHS, A. J. 1978. Microorganisms and heavy metal toxicity. Microbial Ecology 4: 303-317.

GAMS, W., M. CHRISTENSEN, AND A. H. ONIONS. 1985. Infrageneric taxa of Aspergillus. In: Samson R.A., Pitt J.I., editors. Advances in Penicillium and Aspergillus Systematics. Plenum Press; New York: pp. 55-62.
GAVRILESCA, M. 2004. Removal of heavy metals from the environment by biosorption. Eng. Life Sci. 4(3): 219-232.

GEISER, D. M., R. A. SAMSON, AND J. VARGA. 2008. A review of molecular phylogenetics in Aspergillus and prospects for a robust genus-wide phylogeny. In: Varga K., Samson R.A., editors. Aspergillus in the genomic era. Academic Publishers; Wageningen: pp. 17-32.

GUPTA, R., P. AHUJA, S. KHAN, R. K. SAXENA. AND H.MOHAPATRA. 2000. Microbial biosorbents meeting challenges of heavy metal pollution in aqueous solutions, Current Sciences 78: 967-973

JAYARAMAN, M. AND R. ARUMUGAM, 2014. Metal tolerance analysis of microfungi isolated from metal contaminated soil and wastewater. J Microbiol Biotech Food Sci. 4 (1): 63-66.

KAPOOR, A., AND T. VIRARAGHAVAN, 1997. Heavy metal biosorption sites in Aspergillus niger, Bioresource. Technology 61: 221-227.

KHAN, A. G. 2001. Relationship between chromium biomagnification ratio accumulation factor and mycorrhizal in plants growing on tannery effluents polluted soils, Journal of Environment International 26: 417-423.

KUYUCAK, N. AND B.VOLESKY. 1988. Biosorbents for recovery of metals from industrial soluteions. Biotechnol. Lett. 10: 137-142.

MALIK, A. 2004. Metal bioremediation through growing cells. Environment International Journal 30: 261278.

MANAY, N., L. PERERA, AND Z. COUSILLUS, 1999. Lead contamination in vraguay, Review of environmental contamination toxicology 159: 25-39.

MARTIN, F., P. RUBINI, R. COTE, AND I. KOTTKE. 1994. Aluminum polyphosphate complexes in the mycorrhizal basidiomycete Laccaria bieolor. a2VA1 nuclear magnetic resonance study. Planta 194: 241246.

MONIKA, N.B., M. VARGHA, T. ZSÓFIA, M. DONÁT, V. CRISTINA, S. RAQUEL, V. CARLA, M. WIELAND, AND B. JOÃO, 2017. Fungal Contaminants in drinking Water Regulation? A Tale of Ecology, Exposure, Purification and Clinical Relevance. Int. J. Environ. Res. Public Health 2017, 14: $1-40$.

MONISHA, J., T.TENZIN, A. NARESH, B. M. BLESSY, AND N. B. KRISHNAMURTHY, 2014. Toxicity, mechanism and health effects of some heavy metals. Interdisciplinary Toxicology. 2014; Vol. 7(2): 60-72.

MYROLD, D. D. AND NASON, G. E. 1992. Effect of acid rain on soil microbial processes. In. Mitchell R, ed. Environmental Microbiology. New York. WileyLiss; 59-81.

NGODIGHA, E. N., F. O. OLAYIMIKO, B. M. ORUWARI, E. K. E. EKWEOZOR, AND WHEKHE, S. N. 1999. Toxic effects of crude oil in 
organs and blood cells of west Africa dwarf goat, Nigeria Vitinary Journal 20: 82-91.

MAGWAZA,N.M., E. N. NXUMALO, B. B. MAMBA. AND T. A. M. MSAGATI. 2017. The Occurrence and Diversity of Waterborne Fungi in African Aquatic Systems: Their Impact on Water Quality and Human Health. Int. J. Environ. Res. Public Health. 14:1-10.

OMEIKE, S. O., S. O. KAREEM, S. ADEWUYI, AND S. A. BALOGUN. 2013. Biosorption of aluminum from solution by powder Aspergillus oryzae Biomass isolated from aluminum Mill waste site. Journal of Science 15 (1): 119-124.

PARAMESWARI, E. A., LAKSHMANAN. AND T. THILAGAVATHI. 2010. Biosorption and metal tolerance potential of filamentous fungi isolated from metal polluted ecosystem. Electron. J. Environ. Agric. Food. Chem. 9 (4): 664- 671.

PAVANI, K. V. AND N.S. KUMAR. 2013. Adsorption of Iron and Synthesis of Iron Nanoparticles by Aspergillus species Kvp 12. Amer-ican Journal of Nanomaterials, Vol. 1, No. 2: 24-26.

PLAZA, G., W. LUKASIK, AND K. ULFIG. 1996. Sorption of cadmium by filamentous soil fungi. Acta Microbiologica Polonica 45: 193-201.

RAPER, K. B. AND D. J. FENNELL. 1965. The genus Aspergillus. P. 686, Williams and Wilkins, Baltimore, U.S.A.

RICE, E. W., B. RODGER, A. D. E. BAIRD, AND S. C. LENORE. 2012. Standard Methods for Examination of Water and Wastewater. $22^{\text {th }}$ edition,
Washington, DC: American Public Health Assn. pp. 3347.

ROGELIO, G. P. AND C. CARLOS. 1996. Microbial interactions with aluminium. BioMetals. 9, 311-316.

SABAT, J. AND N. GUPTA. 2006. Effect of manganese on growth of fungi obtained from joda mines of Orissa. Asian J. of Bio Sci. Vol. 1 No. 2: 165-167

SAMSON, R.A., E. HOEKSTRA, V.C. FRISVAD, AND O. FILTENBURG. 1996. Introduction to Food Borne fungi, 5th ed. Centraalbureau voor Schimmelcultures. Baarn, the Netherland, 247 pp.

VADKERTIOVA, R. AND E. SLAVIKOVA. 2006. Metal tolerance of yeasts isolated from water, soil and plant environments. J. Basic Microbiol. 46: 145152.

VAISHALY A. G., B. BLESSY, N. B. MATHEW, KRISHNAMURTHY. AND T. P., KRISHNAMURTHY. 2015. Bioaccumulation of heavy metals by fungi. Int J. Env Chem Chrom, Vol. 1 (1): 15-21.

VERMA, T., T. SRINATH, R. U. GADPAYLE, P. W. RAMTEKE, R. K. HANS, AND S. K. GARG. 2001. Chromate tolerant bacteria isolated from tannery effluent. Bioresour. Technol 78: 31-35.

YAMASOET, M. A., P. ARTAXO, A. MIGUEL, AND A. G. ALLEN. 2000. Chemical composition of aerosol particle from direct emission of vegetation fire in Amazon basin. Water soluble spices and trace elements, Atmospheric Environment 34: 1641-1653.

ZEL, J., J. STEVEK, H. CRNE, AND M.SCHARA. 1993. Effects of aluminum on membrane fluidity of the mycorrhizal fungus Amanita muscarm. Physiol Plant 89: 172-17 
التحمل و الامتصاص الحيوي للمنجنيز و الحديد و الالومنيوم بواسط خمسة أنواع من فطر الأسبرجيليس المعزولة من المياه العذبة

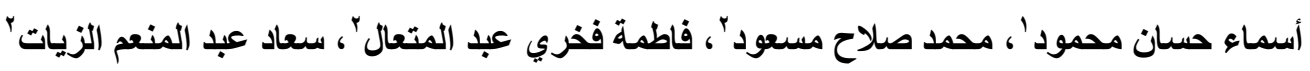

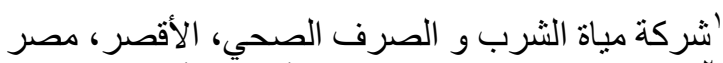

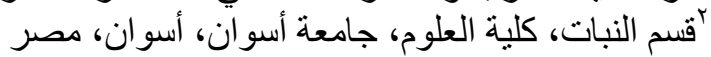

الملخص العربي

تلعب الكائنات الحية الدقيقة دورا هاما في المعالجة الحيوية للتربة ومياه الصرف الصحي الملوثة بالمعادن الثقيلة. وقد أجريت

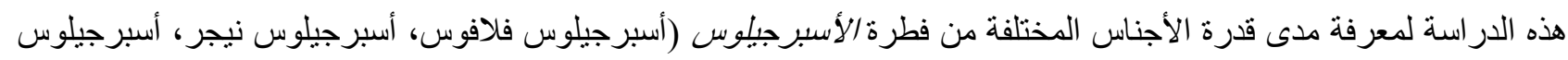
نيديو لانس، أسبرجيلوس اوريزي و أسبرجيلوس تيريوس) لمقاومة العناصر الثقيلة ونلك للعينات التي تم عزلها من مياه نهر النيل. وقد تم قياس درجات المقاومة المختلفة للفطريات قيد الدراسة عن طريق فياس تنبيط النمو للفطريات بإستخدام تركيزات مختلفة

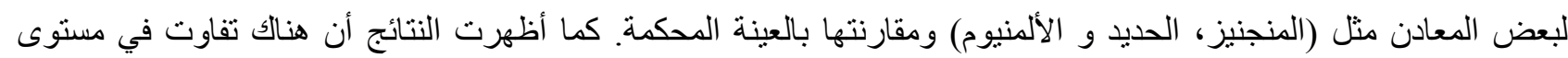

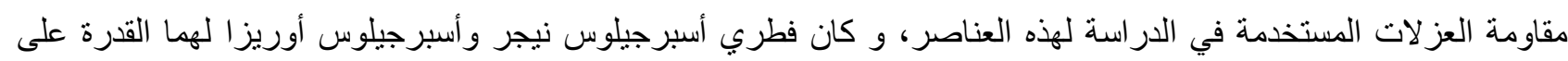
المقاومة في حين فطر أسبرجيلوس نيدولانس كان هو الأكثر حساسية. بالإضافة لذلك تم إختبار قدرة فطر أسبرجيلوس أوريزي

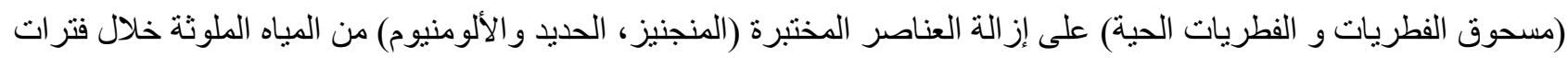
زمنية مختلفة، حيث أظهرت هذه الدراسة مقدرة الفطر على از الة العناصر المستخدمة بكميات كثيرة في غضون ساعتين و ذلك بزيادة كمية الفطر. 